\title{
Age-Related Dynamics of Self-Attitude, Subjective Control and Personality Reflexion Indices
}

\author{
Drandrov G.L. \\ I.Y. Yakovlev Chuvash State Pedagogical University \\ Cheboksary, Russia \\ gerold49@mail.ru
}

\author{
Zorin S.D. \\ I.Y. Yakovlev Chuvash State Pedagogical University \\ Cheboksary, Russia \\ zorin.dm@mail.ru
}

\author{
Burtsev V.A. \\ Povolzhskaya State Academy of Physical Culture, Sport and Tourism \\ Kazan, Russia \\ volder1968@mail.ru
}

\begin{abstract}
The article presents the results of the experiment among three groups of the respondents: 114 teen-agers at the age of 13-14, 23 boys at the age of 16-17 and 59 students at the age of 19-22. Measuring self-attitude, subjective control and personal reflexion indices using the methodologies of psychodiagnostics showed that adolescence in comparison with early youth age has higher indices of open attitude and self-attachment and relatively low indices of self-acceptance, inner conflictness and selfincrimination. During early youth age there is open attitude and self-attachment indices decrease, high indices of self-acceptance are combined with the increased level of inner conflictness and self-incrimination inclination. At the age of 19-22 there is open attitude, self-confidence, self-attachment increase, considerable inner conflictness and self-incrimination decrease. The level of subjective control and the ability to realize reflexion considerably increases. At the same time, the indices of self-management decrease.
\end{abstract}

Keywords-age-related dynamics; self-attitude; subjective control; personal reflexion.

\section{INTRODUCTION}

During recent 20 years there were a lot of changes in Russia. The epoch of totalitarism was changed by the epoch of democratic transformations in all spheres of society - political, social-economic and spiritual. Modern person feels freedom in defining his life plans, aims, intentions, he realizes and understands himself as an active subject of own life. On the other hand, in these new conditions of life, when habitual stereotypes of behavior and activity are ruined, together with freedom a person has to be responsible for his own fate, solve independently the problems of self-determination, not taking into account social and state help.

Nowadays society needs people, who have creative thinking, who are ready to make non-standard decisions in problem situations, to realize self-improvement and selfdevelopment during the whole life. In the Russian Federation law of December, 29, 2012 No 273 "On education in the Russian Federation" it is said that education should be oriented towards self-determination of a personality, the conditions creation for its realization [5].

Characterizing the existing in modern pedagogics situation, G.A. Tsukerman [10] underline, that "the problem of self-development rushed into modern pedagogical awareness, like the released genie (genie, who has no wise master) and started to create new palaces for new masters (the ideas, which proclaim primacy of individual over global) and ruin the palaces of the former masters (the ideas, which produce individual consciousness from social)".

In legislative documents and in educational practice more often the terms are used. They have prefix "self". It characterizes a person as the subject of self-development, selfdetermination and creative self-realization. The first pedagogical objective becomes the objective of personality upbringing with a positive Self-conception, independent and responsible for own life and professional career, as the sphere of own creative abilities realization and the needs satisfaction for personal self-realization $[1,2,6]$. A considerable characteristic of educational activity starts to be pedagogical control over the process of creative personality creation and development, ready for self-development and self-realization $[3,9]$.

In general, legislative documents, other programnormative materials, psychological-pedagogical literature and pedagogical practice analysis and summarizing proves socialpractical importance increase of solving the problem of personality formation with a positive Self-conception, ready for self-affirmation, self-development and creative selfrealization.

A successful realization of this objective in educational process provides age-related peculiarities of different sides of personality's self-concept taking into consideration. At the same time, literature analysis proves insufficient consideration of this problem.

\section{MATERIALS AND METHODS}

The aim of this work is to study age-related dynamics of self-concept, subjective control and personal reflexion indices. 
For this problem solution we used the complex of scientific research methods. It includes theoretical analysis and scientific-methodical literature summarizing, methodology of psychodiagnostics and the methods of mathematical statistics.

The following methodologies of psychodiagnostics were used: the methodology of self-concept study [7]; the methodology of subjective control study [8]; the methodology of personality's ability study to personal reflexion, created by G.L. Drandrov [4].

For quantitative analysis of psychodiagnostics results we used parametric Student t-test.

Three groups of the respondents took part in the research: 114 teen-agers at the age of 13-14, 23 boys at the age of 16-17 and 59 students at the age of 19-22.

\section{RESULTS}

Table I presents self-concept indices, revealed among the respondents of three groups - teen-agers, adolescents and students.

\section{TABLE I. SELF-CONCEPT INDICES AMONG TEEN-AGERS, ADOLESCENTS AND STUDENTS, POINTS $(\mathrm{X} \pm \Sigma)$}

\begin{tabular}{|c|c|c|c|c|c|c|}
\hline \multirow[b]{2}{*}{$\begin{array}{l}\text { Kinds of } \\
\text { self-concept }\end{array}$} & \multicolumn{3}{|c|}{ Groups of respondents } & \multicolumn{3}{|c|}{$P$} \\
\hline & $\begin{array}{l}\text { teen- } \\
\text { agers, } \\
\mathrm{n}=114\end{array}$ & $\begin{array}{c}\text { adolescent } \\
\mathrm{s}, \\
\mathrm{n}=23\end{array}$ & $\begin{array}{l}\text { students, } \\
\mathrm{n}=59\end{array}$ & $1-2$ & $1-3$ & $2-3$ \\
\hline $\begin{array}{l}\text { Open } \\
\text { attitude }\end{array}$ & $\begin{array}{c}6.54 \pm 1.3 \\
1 \\
\end{array}$ & $6.04 \pm 1.02$ & $\begin{array}{c}6.63 \pm 1.4 \\
1 \\
\end{array}$ & 0.09 & 0.68 & 0.07 \\
\hline $\begin{array}{l}\text { Self- } \\
\text { confidence }\end{array}$ & $\begin{array}{c}5.63 \pm 1.5 \\
8 \\
\end{array}$ & $5.17 \pm 1.19$ & $\begin{array}{c}6.21 \pm 1.7 \\
4 \\
\end{array}$ & 0.20 & 0.04 & $\begin{array}{l}0.01 * \\
*\end{array}$ \\
\hline $\begin{array}{l}\text { Self- } \\
\text { managemen } \\
\mathrm{t}\end{array}$ & $\begin{array}{c}6.77 \pm 1.5 \\
5\end{array}$ & $7.22 \pm 1.41$ & $\begin{array}{c}5.74 \pm 1.3 \\
0\end{array}$ & 0.21 & $\begin{array}{l}0.01 * \\
*\end{array}$ & $\begin{array}{l}0.01 * \\
*\end{array}$ \\
\hline $\begin{array}{l}\text { Reflected } \\
\text { self-concept }\end{array}$ & $\begin{array}{c}6.01 \pm 1.5 \\
0 \\
\end{array}$ & $5.78 \pm 1.17$ & $\begin{array}{c}6.15 \pm 1.5 \\
7 \\
\end{array}$ & 0.50 & 0.59 & 0.32 \\
\hline Self-worth & $\begin{array}{c}6.29 \pm 1.5 \\
8 \\
\end{array}$ & $6.04 \pm 1.15$ & $\begin{array}{c}5.97 \pm 1.1 \\
3 \\
\end{array}$ & 0.49 & 0.17 & 0.79 \\
\hline $\begin{array}{l}\text { Self- } \\
\text { acceptance }\end{array}$ & $\begin{array}{c}6.13 \pm 1.9 \\
6 \\
\end{array}$ & $7.39 \pm 2.50$ & $\begin{array}{c}6.89 \pm 1.9 \\
8 \\
\end{array}$ & $\begin{array}{l}0.01 * \\
*\end{array}$ & $0.02 *$ & 0.33 \\
\hline $\begin{array}{l}\text { Self- } \\
\text { attachment }\end{array}$ & $\begin{array}{c}6.25 \pm 1.5 \\
1 \\
\end{array}$ & $5.65 \pm 1.11$ & $\begin{array}{c}6.60 \pm 1.7 \\
2 \\
\end{array}$ & 0.08 & 0.19 & $\begin{array}{l}0.02 * \\
* \\
\end{array}$ \\
\hline $\begin{array}{l}\text { Inner } \\
\text { conflictness }\end{array}$ & $\begin{array}{c}5.29 \pm 1.2 \\
2 \\
\end{array}$ & $6.30 \pm 1.99$ & $\begin{array}{c}4.52 \pm 1.8 \\
3 \\
\end{array}$ & $\begin{array}{l}0.01 * \\
* \\
\end{array}$ & $\begin{array}{l}0.01 * \\
* \\
\end{array}$ & $\begin{array}{l}0.01 * \\
*\end{array}$ \\
\hline $\begin{array}{l}\text { Self- } \\
\text { incriminatio } \\
\mathrm{n}\end{array}$ & $\begin{array}{c}4.98 \pm 1.6 \\
2\end{array}$ & $5.91 \pm 1.04$ & $\begin{array}{c}4.58 \pm 1.8 \\
1\end{array}$ & $\begin{array}{l}0.01 * \\
*\end{array}$ & 0.16 & $\begin{array}{l}0.01 * \\
*\end{array}$ \\
\hline
\end{tabular}

Comparative analysis of self-concept indices proves, that during early adolescence (16-17 years-old) there is less open attitude (6,04 points) in comparison with teenage ( 6,54 points) and youth (6,63 points) age. It proves that at the age of 16-17 there is insignificant importance increase of social approval. In general, the respondents of all age groups, the indices of open attitude are more than the average values. It is explained by the influence of systematic sports activity. It provides close and sincere competition and cooperation, deeper penetration of a personality into oneself, self-realization and open true attitude to oneself.

The same tendency is observed in self-confidence indices dynamics: among teen-agers this index is 5,63 points. During early adolescence we see its decrease till 5,17 points. During studentship this index considerably increases till 6,21 points. The differences according to this index among students, on the one hand, and teen-agers and adolescence, on the other hand are statistically valid $(\mathrm{P}<0,01)$. We can come to the conclusion, that during adolescence there is satisfaction decrease with own abilities. There is also self-distrust increase. During studentship we see attitude to oneself as a confident, independent, strong and reliable person. Who has the reason to be respected.

The opposite tendency is seen in the dynamics of selfmanagement indices. Young men have higher values of selfmanagement in comparison with teen-agers (7,22 and 6,77 points). During studentship self-management index decreases quickly (till 5,74 points). It is less, than among teen-agers and youth. The received results prove that for young men it is typical to be led by own mindsets in their behavior (youthful maximalism). When growing we see the tendency to of taking into consideration close social environment.

In the indices of the reflected self-concept, which show what the respondents think about the attitude of people towards them, there were no considerable differences between the respondents from three groups. Almost the same tendency is in the age-related dynamics of self-worth indices. They characterize respondents' self-evaluation of own personality.

During an early adolescence we see self-acceptance indices increase - from 6,13 among teen-agers till 7,39 points $(\mathrm{P}<0,01)$. It proves that young men are prone to accept themselves how they really are. At the age of 19-20 this index decreases, however, it still increases the indices among teenagers (6,89 points). The differences between teen-agers and students are valid $(\mathrm{P}<0,01)$.

At the same time, young men have relatively low selfattachment indices, in comparison with teen-agers and students (5,65 points). Among teen-agers this index is 6,25 points, among students it increases till 6,60 points. The differences between young men and students are statistically valid $(\mathrm{P}<0,01)$, between teen-agers and young men they are close to valid values ( $\mathrm{P}=0,08$ points). The received results show that young men are emotionally less connected with themselves, although they have high indices of selfacceptance. Indirectly it is proved by high indices of inner conflictness $(6,30$ points), among teen0agers they are considerably lower (5,29 points) and even less among students (4,52 points). We can come to the conclusion that starting from teen-age time there is inner conflictness increase, which during studentship considerably decreases.

High level of inner conflictness during adolescence goes together with high index of self-incrimination (5,91 points). Among teen-agers this index is 4,98 points, among students it decreases till 4,52 points. The differences according to this index between young men, on the one hand and teen-agers and student, on the other hand, are statistically valid $(\mathrm{P}<0,01)$.

Comparative analysis of subjective control indices revealed that for teen-agers and young men it is typical to have higher indices of externality (10,63 and 11,09 points) in comparison with the indices, which were among students (8,92 points). The differences are statistically valid. It proves 
[9] Tikhonov A.S., Drandrov G.L., Kisapov N.N. Connection of motivationalvolitional sphere development with "Self" image formation. Education and self-education. 2009, vol. 4(14), pp. 198-204.

that during studentship the ability of self-control and selfmanagement considerably increases. There is also understanding increase of the fact that a person himself, but not someone else, is the main reason of own achievements and failures.

This age-related tendency is seen in the dynamics of personal reflexion indices. We revealed that both teen-agers and young men have lower level of the ability to reflexion in comparison with students. Students' indices of reflexion are 32,60 points. It increases the values, revealed among teenagers (29,52 points) and young men (29,78 points).

\section{CONCLUSION}

Summarizing the results of the experiment we come to the conclusion that teenage time and early adolescence are characterized by considerable changes in self-concept, subjective control and personal reflexion indices. It is conditioned by transfer of a personality from childhood to the period of adolescence.

It is experimentally stated that during teen-age time, in comparison with early youth age, there are higher indices of open attitude and self-attachment and relatively lower indices of self-acceptance, inner conflictness and self-incrimination. During early youth age there is open attitude and selfattachment indices decrease, high indices of self-acceptance cooperate with the increased level of inner conflictness and self-incrimination. During studentship there is open attitude level, self-confidence, self-attachment increase. There is also considerable inner conflictness and self-incrimination indices decrease. The level of subjective control and the ability to reflexion also increase, in comparison with teen-age time and early youth age. The indices of self-management considerably decrease.

In general, the results of our research work show that teen-age time, youth age and studentship are characterized by considerable changes concerning own personality. It provide the ability development to realize self-determination.

\section{References}

[1] Amonashvili Sh.A., The basis of humane pedagogics in 20 books, the $3^{\text {rd }}$ book School of life. - Moscow: Armita- Rus publishing house. 2012, 320.

[2] Andreev V.I., Pedagogics of creative self-development: in 2 books. Book 1. - the $3^{\text {rd }}$ edition - Kazan: Center of innovative technologies. 2012, 567.

[3] Drandrov G.L., Simonova O.Y., The peculiarities of "Self" image among highly-qualifies athletes and its influence on motivational-volitional sphere development. Theory and practice of physical culture. 2012, vol. 1, pp. 3-8.

[4] Drandrov G.L. Theoretical and organizational-methodical basis of physical culture teacher's readiness formation for creative activity- Cheboksary: Chuvash State Pedagogical University. 2007, 353.

[5] Law of the Russian Federation of December, 29, 2012 No 273 "On education in the Russian Federation". URL: http://base.garant.ru/57422614/

[6] Maralov V.G., The basis of self-actualization and self-development: manual. Moscow: Academy. 2004, 256.

[7] Panteleev S.R., Stolin V.V., Methodology of self-attitude study. Educational aid in psychodiagnostics. The definite psychodiagnostics methodologies. Moscow. 1989, pp. 166-172.

[8] Raygorodsky D.Ya., Practical psychodiagnostics. Methodologies and tests. Samara: Publishing house "BAKHRAKH -M". 2008, 672.
[10] Tsukerman G.A., Masterov B.M., Psychology of self-development. Moscow: Interpraks. 1995, 288. Dynamics of respiratory system indices among biathlonists during a longterm training. The Russian Journal of Physical Education and Sport. 2018, vol. 13(2), pp. 28-32. DOI: 10.14526/02_2018_305.
[11] Gibadullin I.G., Korbit M.I., Voropai M.K., Smirnova I., Smirnova K. 